\title{
Influence of city municipal waste disposal on groundwater quality and assessment of groundwater suitability in agriculture.
}

\author{
Jeykumar R.K.C. ${ }^{*}$ and Chandran S. \\ Department of Civil Engineering, Thiagarajar College of Engineering, Thirupparankundram, Madurai-625009, Tamil Nadu, India \\ Received: 24/12/2017, Accepted: 18/03/2018, Available online: 03/07/2018 \\ *to whom all correspondence should be addressed: e-mail: rkcjey@gmail.com
}

\begin{abstract}
This study focuses on the impact of the disposal of Tirunelveli city municipal waste in the quality of groundwater in Ramayanpatti village where the waste is disposed; the study also assesses the quality of the groundwater suitability in irrigation in the disposed region. Tirunelveli city generates municipal waste of nearly $15 \mathrm{MLD}$ of domestic wastewater and 100 tons of solid waste in a day. The domestic wastewater is treated by waste stabilization pond. The solid waste is dumped in the open yard. These two disposal sites are located in the Ramayanpatti area and their boundaries are at a distance of $500 \mathrm{~m}$ from each other. Ground water resources are extracted in use for agriculture in the area of Ramayanpatti. Around thirty, locations have been identified in the Ramayanpatti area for sampling, based on the contour and flow direction. The dominant chemical cation species in the majority of the groundwater samples are in the order of $\mathrm{Na}>\mathrm{Ca}>\mathrm{Mg}>\mathrm{K}$ and anion species are in the order of $\mathrm{HCO} 3>\mathrm{Cl}>\mathrm{SO} 4>\mathrm{NO} 3$. Gibbs plot shows that the region is dominated by evaporation and dilution phenomenon. Rhode's plot shows that there is no reduction in the rate of infiltration of soil in the Ramayanpatti region. Dendrogram shows that the leachates infiltration is predominant in the winter season. The study shows that the groundwater quality, nearer and to the southeastern side of the disposal sites are most affected and contaminated by solid waste leachates. The inference with various irrigation plots show that the quality of groundwater in the southeastern region is doubtful for use in irrigation and the groundwater needs to be assessed in order to use in irrigation for agriculture.
\end{abstract}

Keywords: sewage, solid waste, leachates, groundwater pollution, agriculture and irrigation, dendrogram.

\section{Introduction}

\subsection{Background}

Rapid urbanization, agricultural activities and industrialization led to large withdrawal of groundwater resources (Causape et al. 2004; Mohsen Jalali, 2011). The groundwater is depleting at an alarming rate than ever. Also, rapid urbanization and mushrooming of industries escalated pollution in the environment i.e. in waterways, air, soil and groundwater. With the disposal of increased domestic sewage and industrial effluent into the waterways and dumping of solid waste on the available common lands resulted infiltration into the soil during rainy seasons and affected the quality of ground water adversely (Pande et al., 2015; De et al., 2016). The continuous use of highly polluted ground water in irrigation will cause serious damage to the crop and soil by way of reducing infiltration (Rhoades, 1968), making it unfit for cultivation. Hence, in the locations of municipal waste disposal site there is a strong need for analyzing the impact of municipal waste disposal on the quality of ground water in order to assess its suitability for irrigation. One such critical location is the Ramayanpatti village which is located on the outskirts of Tirunelveli district where municipal waste is disposed off as well as mining of limestone is carried out to the northeast of this village. Hydro-chemical investigation has been conducted by collecting ground water samples from the bore wells surrounding Ramayanpatti village to know the suitability of ground water for irrigation.

\subsection{About the area investigated}

\subsubsection{General}

Ramayanpatti village of Manur block (Panchayat Union) is in the outskirts of Tirunelveli district, in close proximity to Tirunelveli city. Tirunelveli is the sixth biggest city in Tamilnadu having a population of 4.75 lakh as per the 2011 census data. This city is located in the southern part of the state as shown in the Fig. 1 . The sewage and the solid waste generated by the city are disposed in this village area. The sewage water is let into the stabilization ponds constructed for treating the effluent through natural process and the solid waste is dumped on the open yard at about $500 \mathrm{~m}$ away from this stabilization pond. The stabilization ponds spread over an area of two hectares, are lined with clay at their bottom, and the side slopes are lined with concrete slabs in order to arrest seepage into the ground.

\subsection{Geology and Lithology}

The topography of the Tirunelveli district is a flat, sloping terrain in nature and the altitude is $36.39 \mathrm{~m}$ above MSL and is endowed with small mountains and hillocks. The geology of the site is hornblende-biotite gneiss structure. The geomorphology is buried pediment shallow and pediment 
with black cotton soil to the complex outcrop. The top soil is 1 to $3 \mathrm{~m}$ below ground level. The fractured rocks occur at 20 to $40 \mathrm{~m}$ below ground level. The soil is very deep, moderately well drained, clayey soils on nearly level lowlands, slightly eroded, associated with moderately deep, moderately well drained, loamy soils. The soil is classified as fine, loamy, mixed and typical ustropepts. The area is covered by red sandy soil on top and black cotton soil at the bottom. The River alluvial soils occur along the river courses of Tamirabarani and Chittar river covering the blocks of Tirunelveli and Palayankottai. The borehole lithology of the study area indicates there is a considerable thickness of the topsoil and has a thickness of about $2.5 \mathrm{~m}$, which is underlain by a clay layer of about $15 \mathrm{~m}$ thickness and weathered rock layer of $25 \mathrm{~m}$.

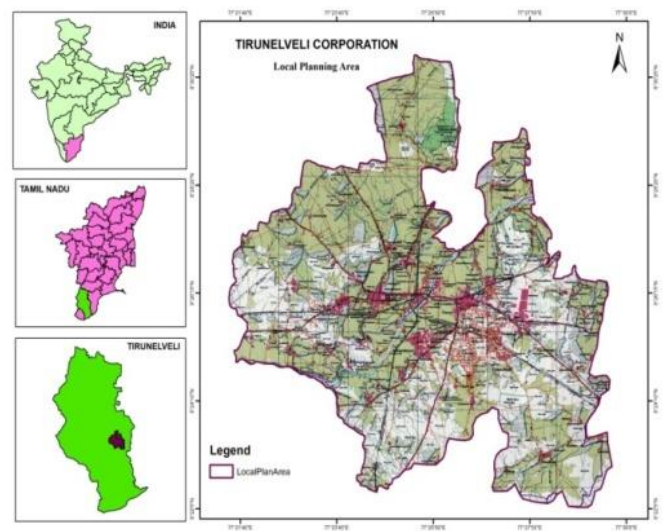

Figure 1. Location of the study area

\subsection{Climate and rainfall}

The climate of the Tirunelveli district is tropical, having a minimum and maximum temperature of $25.11{ }^{\circ} \mathrm{C}$ to

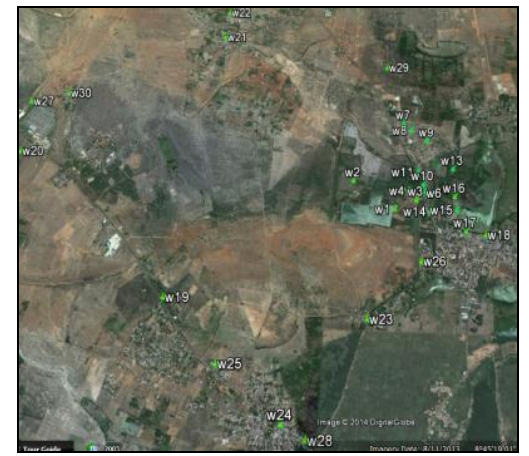

$34.30{ }^{\circ} \mathrm{C}$ respectively. The monthly average relative humidity varies from $62.19 \%$ to $78.13 \%$. The minimum and maximum average wind velocity in $\mathrm{KMPH}$ are 3.00 to 11.80 . The humidity is maximum during the month of OctoberDecember and it is as high as $98 \%$ during the month of November. The minimum humidity is noticed in the month of May which is as low as $29 \%$. The annual average rainfall is $956 \mathrm{~mm}$, distributed during the North East monsoon season $(555.08 \mathrm{~mm})$, South West monsoon season (189.6 mm), summer (127.7 mm) and winter (74.5 mm).

\subsection{Hydro-Meteorology}

The Hydro-meteorological feature of the study area divides the year into two major classifications as 1) Winter season spanning from June to December and 2) Summer season spanning from January to May. As the winter period brings heavy rainfall, it improves the recharging of groundwater and storage of surface water.

\section{Methods and techniques}

\subsection{Objective of the study}

a) To study the impact of municipal waste disposal on groundwater by hydro chemical investigation, and

b) To assess the groundwater suitability for irrigation surrounding the municipal waste disposal site.

\subsection{Data collection and synthesis}

A reconnaissance survey is carried out to find out the location of sampling points surrounding the treatment plant and open yard dumping site. The sampling points are so selected that the majority of the points are located near the disposal site where aquifer groundwater movement is possible, which is inferred based on the USGS DEM contour of the Ramayanpatti area, shown in Fig.2.

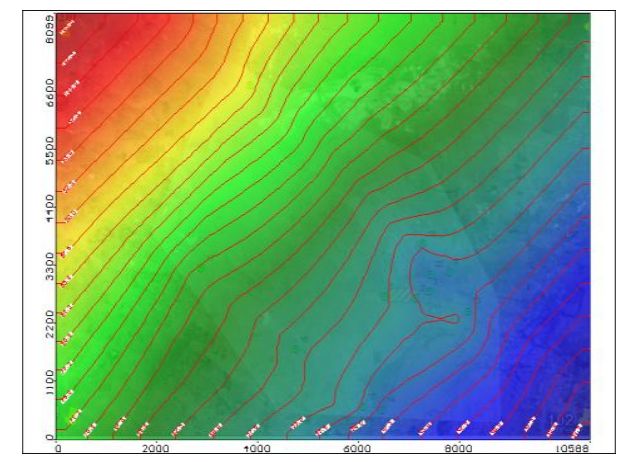

Figure 2. Satellite image of sampling points and Contour of the study area (Source: Google image and USGS DEM image)

Intensive sampling, preservation, storing and analysis have been carried out as per APHA (American public health association) standards 1999. Around thirty sampling points have been identified surrounding solid waste dumping yard and wastewater treatment site at Ramayanpatti. The aerial extent of the sampling area is 10 square kilometers. These sampling sites are located in the state district roads en route to Tenkasi on the western side, enroute to Sankarankovil on the eastern side and also in the village roads near the disposal sites. The sampling points are tagged from W1 to W30, marked circular, colored green, shown in Fig. 2 of google image. The identified groundwater sampling sites are mapped to Geo coordinates with GPS (Global positioning system) instrument, for plotting groundwater quality parameters. The contour of the study area is drawn by the DEM (Digital elevation model) image of USGS (United States Geological survey), shown in Fig. 2 -contour of the study area. The higher elevation of the study area is at the top left-hand corner shown in red color, and the lower elevation is at the 
bottom right hand corner shown in blue color. The elevation of the study area is decreasing from top left corner of the image to the bottom right corner of the image which is shown in Fig. 2. The treatment plant i.e. waste stabilization pond is visible as rectangular plots in the google image of Fig. 2, located near the w1 sampling point. The solid waste dumping yard is visible as slightly white/grey, irregular, located near the sampling point w4 in the google image of Fig. 2.

\subsection{Groundwater Characterization}

The groundwater samples are collected at thirty sampling points during the summer season and winter season. The collected groundwater samples are characterized for general water quality parameters such as $\mathrm{pH}, \mathrm{EC}$ (Electrical conductivity), TDS (Total dissolved solids), COD (Chemical oxygen demand), DO (Dissolved oxygen), Total Alkalinity, Total Hardness, Cations such as Sodium, Potassium, Calcium, Magnesium Anions such as Bicarbonates, chlorides, sulfates, and Nitrates. The heavy metals concentration is below the deductable limit and is not discussed here. The water quality parameters are measured in $\mathrm{mg} \mathrm{l}^{-1}$, hardness and alkalinity in $\mathrm{mg} \mathrm{I}^{-1}$ equivalent to $\mathrm{CaCO}_{3}$. SARadj, \% Sodium ratio, calcium, magnesium, TDS, chloride and Bicarbonate hardness are used for graphical representation of Gibb's diagram, Trilinear diagram, Wilcox diagram, Rhoade's diagram and USSL (United States salilnity laboratory) diagram. Generally, the SAR values are used to find out the suitability of groundwater for irrigation. Sodium Absorption Ratio (SAR) Value is considered to be more significant for assessing the suitability of water in irrigation. But adjusted SAR values provide better insight into the water penetration capacity of the soil. The reason is that, this approach takes into account the possible carbonate precipitation into the soil or dissolution of soil calcites in the groundwater when the groundwater infiltrates. The SAR value increases if the groundwater used for irrigation contributes to precipitation, which reduces the water penetration capacity of the soil. Conversely, the SAR value may decrease if the groundwater quality has the ability to dissolve carbonate precipitates from the soil, which in turn increases water penetration capacity. Hence, in this study, more focus is made on adjusted SAR values which are denoted by SARadj and conventional SAR values by SARact. The SARadj is calculated by converting the major cations \& anions into meq $\mathrm{l}^{-1}$ by their respective equivalent weights. The adjusted SAR values are used throughout this study for inference with various irrigation quality plot diagrams. The descriptive statistics table 1 and 2 show the general statistic measures of all the parameters such as range, minimum, maximum, mean, standard error, standard deviation, variance of the study area etc.

\subsubsection{SAR and adjusted SAR calculations}

The SAR and adjusted SAR calculations are done using the following relations as given below.

$$
\operatorname{SAR}(\text { actual })=\frac{\mathrm{Na}}{\left(\frac{\mathrm{Ca}+\mathrm{Mg}}{2}\right)^{0.5}}
$$

$$
\text { SAR (adjusted })=\frac{\mathrm{Na}}{\left(\frac{\mathrm{Ca}_{\mathrm{eq}}+\mathrm{Mg}}{2}\right)^{0.5}}
$$

Where

$\mathrm{Ca}_{\text {eq }}$ is the expected $\mathrm{Ca}$ concentration that exists after equilibrating with the $\mathrm{CaCO} 3$ solid phase present in the soil.

The equilibrated $\mathrm{Ca}_{\text {eq }}$ concentration is calculated from the following equation as suggested by S. M. Lesch, D. L. Suarez and as given below:

$$
\mathrm{Ca}_{\mathrm{eq}}=\left(\frac{\mathrm{k} 1 \mathrm{k} 2 \mathrm{k} 3 \mathrm{P}_{\mathrm{CO} 2}}{\mathrm{k} 4 \Upsilon_{\mathrm{Ca}} \Upsilon_{\mathrm{HCO} 3}\left(\mathrm{HCO}_{3} \times \mathrm{Ca}\right)^{0.5}}\right)^{1 / 3}
$$

Where k1, k2, k3, k4 represents four known chemical equilibrium constants, $\mathrm{HCO}_{3}$ and $\mathrm{Ca}$ represent the bicarbonate and calcium concentrations in milli-mole per litre in the irrigation water, $\Upsilon_{\mathrm{Ca}}$ and $\Upsilon_{\mathrm{HCO}}$ represent the activity coefficients associated with these bicarbonate and calcium concentrations, and $\mathrm{P}_{\mathrm{CO}}$ represents the partial $\mathrm{CO}_{2}$ pressure in the soil surface. This partial $\mathrm{CO}_{2}$ pressure is typically assumed to be 0.0007 atmospherics in this study too, but other values can also be employed if necessary as appropriately as Suarez, 1981. The equation is solved using spreadsheet by finding out the lonic strength and using empirical regression model as given in technical note by $S$. M. Lesch, D. L. Suarez.

\section{Results and Discussion}

This work has been carried out in the region of the Ramayanpatti area covering 10 sq. $\mathrm{Km}$ surrounding municipal waste disposal sites. Hence the conclusion given here is applicable only to this area. The analysis of groundwater quality with descriptive statistics, alteration of permeability of soil by the application of the contaminated groundwater, and irrigation suitability with various plots are discussed here.

\subsection{Descriptive statistics for summer and winter Season}

The groundwater samples are characterized for both summer and winter seasons. Only descriptive statistics of summer and winter seasons are shown in Table 1 and Table 3. These characterizations show that the dilution is predominant during the winter season as may be seen from the minimum and maximum values of the parameters. The groundwater quality parameters such as $\mathrm{pH}$, TDS, Total Hardness increases slightly during summer season which is shown in Table 1 . The parameters such as COD and DO decreases slightly during summer and are due to higher rate of oxidization of COD at higher temperatures, thereby decreasing $\mathrm{DO}$ and hence a slight increase of $\mathrm{pH}$. As the concentration of TDS and chloride are higher; there is a possibility of infiltration of solid waste leachates from the open dump yard. The nitrate concentration in groundwater is higher in the agricultural areas where nutrient urea is used (Jalali 2005; 2011). The spatial distribution of nitrate concentration is shown in Fig.3. The dominant chemical cation species in the majority of the groundwater samples are in the order of $\mathrm{Na}>\mathrm{Ca}>\mathrm{Mg}>\mathrm{K}$ and anion species are in the order of $\mathrm{HCO} 3>\mathrm{Cl}>\mathrm{SO} 4>\mathrm{NO} 3$. The high magnesium species are found at the points in the groundwater flow 
path and are located in the region of mining and dolomite processing areas.

\subsection{Summer Season Analysis}

The descriptive statistics of characterization of the groundwater samples during the summer season is shown in Table 1. The $\mathrm{pH}$ value shows that the groundwater, in general, is neutral to very slightly alkaline which ranges between 7.33 and 8.26 . This shows that the carbonate is not present in most of the samples but may present in smaller quantities in the waters having $\mathrm{pH}$ above 8 (wqd, a\&i). This $\mathrm{pH}$ value increases slightly during this season. The TDS value ranges from 449 to $2611 \mathrm{mg} \mathrm{l}^{-1}$. The TDS at sampling points $W 7, W 11, W 14 \& W 18$ which are in the flow path of groundwater from dumpsite shows a higher concentration of TDS in the range of 1631 to $2611 \mathrm{mg} \mathrm{l}^{-1}$. Similarly, the Total hardness is well within the limits of standards except at the sampling points of W7, W11, W14 \&W18 where the concentration ranges from 1137 to 1723 $\mathrm{mg} \mathrm{l}^{-1}$. Total alkalinity is well within $500 \mathrm{mg} \mathrm{l}^{-1}$ except at some points where it exceeds, and the values vary from 230 to $655 \mathrm{mg} \mathrm{l}^{-1}$. The COD shows higher concentration at points near to the municipal disposal sites and this value ranges from 5 to $56 \mathrm{mg} \mathrm{l}^{-1}$. The DO of the sampling points is generally good, and the values range from 5.83 to $7.38 \mathrm{mg}$ $\mathrm{I}^{-1}$. The calculated TDS/EC ratio is in the range of 0.57 to 0.64. Chlorides and TDS calculated are in the increasing trend which shows that there is a possible contamination of groundwater by infiltration of leachates from dumping yard site.

Table 1. Descriptive statistics for summer season

\begin{tabular}{|c|c|c|c|c|c|c|c|c|}
\hline Parameter & $\begin{array}{c}\text { No of } \\
\text { Samples }\end{array}$ & Range & Minimum & Maximum & Mean & Standard Error & $\begin{array}{l}\text { Standard } \\
\text { Deviation }\end{array}$ & Variance \\
\hline $\mathrm{pH}$ & 30 & 0.93 & 7.33 & 8.26 & 7.642667 & 0.03926 & 0.215037 & 0.046241 \\
\hline $\mathrm{EC} \mu \mathrm{S} / \mathrm{cm}$ & 30 & 4067 & 617 & 4684 & 2290.733 & 195.5409 & 1071.022 & 1147088 \\
\hline Total Alkalinity & 30 & 425 & 230 & 655 & 462.4333 & 21.14752 & 115.8297 & 13416.53 \\
\hline Total Hardness & 30 & 1474 & 249 & 1723 & 700.7 & 65.06508 & 356.3761 & 127003.9 \\
\hline COD & 30 & 51 & 5 & 56 & 17.86667 & 2.287765 & 12.53061 & 157.0161 \\
\hline DO & 30 & 1.55 & 5.83 & 7.38 & 6.557 & 0.078823 & 0.431734 & 0.186394 \\
\hline Calcium & 30 & 238 & 42 & 280 & 125.8333 & 10.93062 & 59.86945 & 3584.351 \\
\hline Magnesium & 30 & 185 & 28 & 213 & 97.16667 & 8.672069 & 47.49888 & 2256.144 \\
\hline Sodium & 30 & 746 & 27 & 773 & 290.7667 & 28.46142 & 155.8896 & 24301.56 \\
\hline Pottasium & 30 & 8 & 19 & 27 & 23.56667 & 0.385613 & 2.112089 & 4.46092 \\
\hline Bicarbonate & 30 & 518 & 281 & 799 & 550.8667 & 27.13397 & 148.6189 & 22087.57 \\
\hline Chloride & 30 & 1149 & 90 & 1239 & 443.2333 & 52.38963 & 286.9498 & 82340.19 \\
\hline Sulphate & 30 & 287 & 26 & 313 & 129.5333 & 13.19602 & 72.27759 & 5224.051 \\
\hline Nitrate & 30 & 52 & 24 & 76 & 36.73333 & 2.34493 & 12.84371 & 164.9609 \\
\hline TDS & 30 & 2162 & 449 & 2611 & 1417.833 & 106.6558 & 584.1778 & 341263.7 \\
\hline SAR act & 30 & 8.78 & 0.78 & 9.56 & 4.676 & 0.3602 & 1.9729 & 3.892 \\
\hline SAR adj & 30 & 11.04 & 0.88 & 11.92 & 5.6487 & 0.45227 & 2.47719 & 6.136 \\
\hline
\end{tabular}

*All parameters are in $\mathrm{mg} / \mathrm{l}$ except $\mathrm{pH}, \mathrm{EC}$, both $S A R$

The two tailed bivariate Spearman calculation is done for the summer season groundwater quality parameters which is shown in Table 2. Table 2 shows the general statistic measures of all the parameters such as range, minimum, maximum, mean, standard error, standard deviation, variance of the study area etc.EC and total alkalinity values show significant correlation with all the major cations and anions at 0.05 levels. It is obvious that the correlation is very significant at 0.01 levels for EC and TDS calculated. The correlation coefficient is 0.959 . Total hardness shows significant correlation with all major cations and anions except potassium and nitrates. COD correlates negatively with DO. Calcium, magnesium and sodium correlate well among them and also with hardness, alkalinity, major cations, major anions, other than potassium, nitrate and TDS. Chlorides correlate well with TDS. Similarly, SAR actual and SAR adjusted values show significant correlation at 0.01 levels and the ratio is 0.994 . Also, both SAR values show that the correlation with sodium is significant at 0.01 levels and the ratio is 0.92 and 0.921 since the SAR values is directly proportional to sodium. Both the SAR values and TDS show significant correlation with bicarbonate at 0.01 levels and the ratio are $0.568,0.593$ and 0.705 . The correlation between SAR values and TDS show significant correlation at 0.01 levels where this correlation ratio are 0.627 and 0.645 . The SAR values and TDS calculated show significant correlation with total alkalinity at 0.01 levels and are 0.627 and 0.645 . The sodium shows significant correlation with chloride and bicarbonate at 0.01 levels and is 0.753 and 0.630 .

\subsection{Winter Season Analysis}

The descriptive statistics of groundwater characterization during summer season is shown in Table 3. The $\mathrm{pH}$ value shows that the groundwater in general is neutral to very slightly alkaline or acidic which varies from 6.91 to 7.66 . This $\mathrm{pH}$ value shows that the carbonate is not present in these waters as per water quality data, analysis and interpretations (wqd a\&i) and the carbonates shall be present if the $\mathrm{pH}$ is above 8 . This range of $\mathrm{pH}$ does not influence ionic balance in waters or the percentage affect is negligible. Normally the $\mathrm{pH}$ values shall be included in the ionic balance if the value of $\mathrm{pH}$ is less than 4 or greater than 10. The TDS value ranges from 460 to $2495 \mathrm{mg} \mathrm{l}^{-1}$. The TDS values are well within the WHO irrigation standards at most points and are above $2000 \mathrm{mg} \mathrm{l}^{-1}$ at points W7, W8, W11, W14 and W25. 
Table 2. Spearman bivariate analysis for summer season

\begin{tabular}{|c|c|c|c|c|c|c|c|c|c|c|c|c|c|c|c|c|c|}
\hline & $\mathrm{pH}$ & EC & TA & $\mathrm{TH}$ & COD & DO & $\mathrm{Ca}$ & $\mathrm{Mg}$ & $\mathrm{Na}$ & $\mathrm{K}$ & $\mathrm{HCO}_{3}{ }^{-}$ & $\mathrm{Cl}^{-}$ & $\mathrm{SO}_{4}{ }^{2-}$ & $\mathrm{NO}_{3}{ }^{-}$ & TDS cal & SARact & SARadj \\
\hline $\mathrm{pH}$ & 1 & & & & & & & & & & & & & & & & \\
\hline EC & 0.14 & 1 & & & & & & & & & & & & & & & \\
\hline TA & 0.3 & $.541^{* *}$ & 1 & & & & & & & & & & & & & & \\
\hline TH & 0.1 & $.895^{* *}$ & $.482^{* *}$ & 1 & & & & & & & & & & & & & \\
\hline COD & 0.01 & 0.31 & 0.2 & 0.34 & 1 & & & & & & & & & & & & \\
\hline DO & -0.28 & $-.374^{*}$ & $-.432 *$ & -0.35 & $-.516^{* *}$ & 1 & & & & & & & & & & & \\
\hline $\mathrm{Ca}$ & 0.12 & $.905^{* *}$ & $.463^{*}$ & $.960 * *$ & $.366^{*}$ & -0.34 & 1 & & & & & & & & & & \\
\hline $\mathrm{Mg}$ & 0.16 & $.854^{* *}$ & $.452^{*}$ & $.969 * *$ & 0.28 & $-.378^{*}$ & $.914^{* *}$ & 1 & & & & & & & & & \\
\hline $\mathrm{Na}$ & 0.26 & $.815^{* *}$ & $.587^{* *}$ & $.689 * *$ & 0.33 & $-.481^{* *}$ & $.725^{* *}$ & $.677^{* *}$ & 1 & & & & & & & & \\
\hline K & -0.13 & 0.04 & -0.1 & -0.04 & -0.36 & $.389^{*}$ & 0 & -0.06 & 0.11 & 1 & & & & & & & \\
\hline $\mathrm{HCO}_{3}^{-}$ & 0.26 & $.596 * *$ & $.974 * *$ & $.559 * *$ & 0.21 & $-.490 * *$ & $.532^{* *}$ & $.526 * *$ & $.630 * *$ & -0.07 & 1 & & & & & & \\
\hline $\mathrm{Cl}^{-}$ & 0.1 & $.967^{* *}$ & $.514^{* *}$ & $.876^{* *}$ & 0.29 & -0.34 & $.884^{* *}$ & $.837^{* *}$ & $.753^{* *}$ & 0.07 & $.585^{* *}$ & 1 & & & & & \\
\hline $\mathrm{SO}_{4}{ }^{2-}$ & 0.08 & $.432^{*}$ & 0.27 & $.569 * *$ & $.407^{*}$ & $-.550^{* *}$ & $.590 * *$ & $.576^{* *}$ & $.389 *$ & -0.27 & 0.33 & 0.36 & 1 & & & & \\
\hline $\mathrm{NO}_{3}^{-}$ & $-.403 *$ & -0.05 & $-.362^{*}$ & 0.05 & -0.25 & 0.34 & 0.02 & 0.05 & -0.08 & 0.19 & -0.34 & -0.13 & 0.17 & 1 & & & \\
\hline TDS cal & 0.2 & $.959 * *$ & $.642^{* *}$ & $.913^{* *}$ & 0.33 & $-.420^{*}$ & $.929 * *$ & $.882^{* *}$ & $.860^{* *}$ & 0.03 & $.705^{* *}$ & $.931^{* *}$ & $.531^{* *}$ & -0.06 & 1 & & \\
\hline SAR act & 0.36 & $.572^{* *}$ & $.544^{* *}$ & $.394^{*}$ & 0.21 & $-.458^{*}$ & $.440^{*}$ & $.402^{*}$ & $.920 * *$ & 0.16 & $.568^{* *}$ & $.504^{* *}$ & 0.18 & -0.18 & $.627^{* *}$ & 1 & \\
\hline SAR adj & 0.36 & $.590 * *$ & $.570^{* *}$ & $.406^{*}$ & 0.23 & $-.470 * *$ & $.462^{*}$ & .399* & $.921 * *$ & 0.15 & $.593^{* *}$ & $.524^{* *}$ & 0.2 & -0.19 & $.645^{* *}$ & $.994 * *$ & 1 \\
\hline
\end{tabular}

Table 3. Descriptive statistics winter season

\begin{tabular}{|c|c|c|c|c|c|c|c|c|}
\hline Parameters* & No of Samples & Range & Minimum & Maximum & Mean & Std. Error & Std. Deviation & Variance \\
\hline $\mathrm{pH}$ & 30 & 0.75 & 6.91 & 7.66 & 7.303 & 0.041064 & 0.224916 & 0.050587 \\
\hline $\mathrm{EC} \mu \mathrm{S} / \mathrm{cm}$ & 30 & 4036 & 635 & 4671 & 2262.033 & 197.9935 & 1084.455 & 1176043 \\
\hline Total Alkalinity & 30 & 380 & 231 & 611 & 425.8333 & 19.00557 & 104.0978 & 10836.35 \\
\hline Total Hardness & 30 & 1395 & 202 & 1597 & 669.3667 & 62.59374 & 342.84 & 117539.3 \\
\hline COD & 30 & 77 & 4 & 81 & 28.4 & 4.054684 & 22.20842 & 493.2138 \\
\hline $\mathrm{DO}$ & 30 & 1.98 & 5.64 & 7.62 & 6.605 & 0.100385 & 0.549832 & 0.302316 \\
\hline Calcium & 30 & 208 & 38 & 246 & 114.9333 & 10.43171 & 57.13682 & 3264.616 \\
\hline Magnesium & 30 & 171 & 25 & 196 & 90.4 & 8.011429 & 43.8804 & 1925.49 \\
\hline Sodium & 30 & 561 & 37 & 598 & 277.8667 & 25.57359 & 140.0723 & 19620.26 \\
\hline Potassium & 30 & 9 & 20 & 29 & 24.6 & 0.43045 & 2.357673 & 5.558621 \\
\hline Bicarbonate & 30 & 497 & 246 & 743 & 507.6333 & 25.11383 & 137.5541 & 18921.14 \\
\hline Chloride & 30 & 1111 & 78 & 1189 & 416.0333 & 50.84248 & 278.4757 & 77548.72 \\
\hline Sulphate & 30 & 274 & 19 & 293 & 125.2333 & 13.32629 & 72.99111 & 5327.702 \\
\hline Nitrate & 30 & 61 & 22 & 83 & 37.26667 & 3.161163 & 17.3144 & 299.7885 \\
\hline TDS & 30 & 2035 & 460 & 2495 & 1390.6 & 102.3787 & 560.7515 & 314442.2 \\
\hline SARact & 30 & 7.52 & 1.14 & 8.66 & 4.691667 & 0.355888 & 1.949278 & 3.799683 \\
\hline SARadj & 30 & 9.59 & 1.29 & 10.88 & 5.611333 & 0.442155 & 2.42178 & 5.865019 \\
\hline
\end{tabular}

${ }^{*}$ All parameters are in $m g / l$ except $p H, E C$, and both $S A R$ values 
Table 4. Spearman two tailed bivariate correlation for winter season

\begin{tabular}{|c|c|c|c|c|c|c|c|c|c|c|c|c|c|c|c|c|c|}
\hline & $\mathrm{pH}$ & $\mathrm{EC}$ & TA & $\mathrm{TH}$ & COD & DO & $\mathrm{Ca}$ & $\mathrm{Mg}$ & $\mathrm{Na}$ & $\mathrm{K}$ & $\mathrm{HCO}_{3}^{-}$ & $\mathrm{Cl}^{-}$ & $\mathrm{SO}_{4}{ }^{2-}$ & $\mathrm{NO}_{3}{ }^{-}$ & TDS cal & SAR act & SAR adj \\
\hline $\mathrm{pH}$ & 1 & & & & & & & & & & & & & & & & \\
\hline EC & -0.27 & 1 & & & & & & & & & & & & & & & \\
\hline TA & $.418^{*}$ & $.442^{*}$ & 1 & & & & & & & & & & & & & & \\
\hline $\mathrm{TH}$ & -0.29 & $.902 * *$ & $.439 *$ & 1 & & & & & & & & & & & & & \\
\hline COD & -0.09 & 0.14 & -0.08 & 0.13 & 1 & & & & & & & & & & & & \\
\hline DO & -0.15 & $-.383^{*}$ & -0.35 & -0.27 & $-.591 * *$ & 1 & & & & & & & & & & & \\
\hline $\mathrm{Ca}$ & -0.25 & $.917^{* *}$ & $.454^{*}$ & $.970^{* *}$ & 0.17 & -0.3 & 1 & & & & & & & & & & \\
\hline $\mathrm{Mg}$ & -0.32 & $.888^{* *}$ & $.406 *$ & $.982 * *$ & 0.13 & -0.3 & $.932 * *$ & 1 & & & & & & & & & \\
\hline $\mathrm{Na}$ & 0.13 & $.749 * *$ & $.602^{* *}$ & $.641 * *$ & 0.11 & $-.490 * *$ & $.674^{* *}$ & $612^{* *}$ & 1 & & & & & & & & \\
\hline $\mathrm{K}$ & -0.15 & 0.05 & -0.11 & 0.01 & $-.430 *$ & $.587^{* *}$ & 0.04 & -0.05 & 0 & 1 & & & & & & & \\
\hline $\mathrm{HCO}_{3}{ }_{3}^{-}$ & $.379 *$ & $.502 * *$ & $.976 * *$ & $.509 * *$ & -0.09 & $-.408^{*}$ & $.519 * *$ & $.478^{* *}$ & $.640^{* *}$ & -0.14 & 1 & & & & & & \\
\hline $\mathrm{Cl}^{-}$ & -0.19 & $.939 * *$ & $.493^{* *}$ & $.872^{* *}$ & 0.13 & -0.33 & $.910^{* *}$ & $.836^{* *}$ & $.681^{* *}$ & 0.06 & $.548^{* *}$ & 1 & & & & & \\
\hline $\mathrm{SO}_{4}{ }^{2-}$ & -0.25 & $.512 * *$ & 0.29 & $.566 * *$ & $.380 *$ & $-.481 * *$ & $.565^{* *}$ & $.605^{* *}$ & $.402 *$ & -0.26 & 0.32 & $.381 *$ & 1 & & & & \\
\hline $\mathrm{NO}_{3}{ }^{-}$ & $-.653^{* *}$ & -0.02 & $-.425 *$ & 0.06 & -0.11 & $.433^{*}$ & -0 & 0.09 & -0.13 & 0.34 & $-.440 *$ & -0.14 & 0.08 & 1 & & & \\
\hline TDScal & -0.1 & $.932 * *$ & $.641^{* *}$ & $.911 * *$ & 0.13 & $-.400 *$ & $.936 * *$ & $.885^{* *}$ & $.815^{* *}$ & -0.01 & $.694 * *$ & $.915^{* *}$ & $.598 * *$ & -0.09 & 1 & & \\
\hline SARact & 0.33 & $.483^{* *}$ & $.559 * *$ & 0.32 & -0 & $-.438^{*}$ & 0.36 & 0.29 & $.910^{* *}$ & -0.04 & $.561 * *$ & $.417^{*}$ & 0.15 & -0.19 & $.548 * *$ & 1 & \\
\hline SARadj & 0.34 & $.507 * *$ & $.594^{* *}$ & 0.34 & -0.01 & $-.423^{*}$ & $.395^{*}$ & 0.31 & $.918^{* *}$ & -0.01 & $.591 * *$ & $.449 *$ & 0.18 & -0.19 & $.585^{* *}$ & $.994 * *$ & 1 \\
\hline
\end{tabular}

*. Correlation is significant at the 0.05 level (2-tailed), **. Correlation is significant at the 0.01 level (2-tailed), TH-Total Hardness, TA-Total Alkalinity 
These points are located in the groundwater flow direction from the solid waste dump yard. Similarly, the total hardness is well within the limit of the irrigation standards at most points except at the sampling points of W7, W11, W14 and W18 where the concentration ranges from 1077 to $1597 \mathrm{mg} \mathrm{l}^{-1}$. Total alkalinity is also generally within acceptable limits and well within $500 \mathrm{mg} \mathrm{l}^{-1}$ except at some points where it exceeds, and the values varies from 231 to $611 \mathrm{mg} \mathrm{l}^{-1}$. The COD does exist in the wells $\mathrm{W} 1, \mathrm{~W} 2$ to $\mathrm{W} 8$ located near the municipal solid waste disposal sites and is above $40 \mathrm{mg} \mathrm{l}^{-1}$. This COD value ranges from 4 to $81 \mathrm{mg} \mathrm{l}^{-1}$. The DO of the sampling points is generally good at all sampling locations and the values range from 5.64 to 7.62 $\mathrm{mg} \mathrm{l}^{-1}$. The TDS to EC varies from 0.55 to 0.74 .
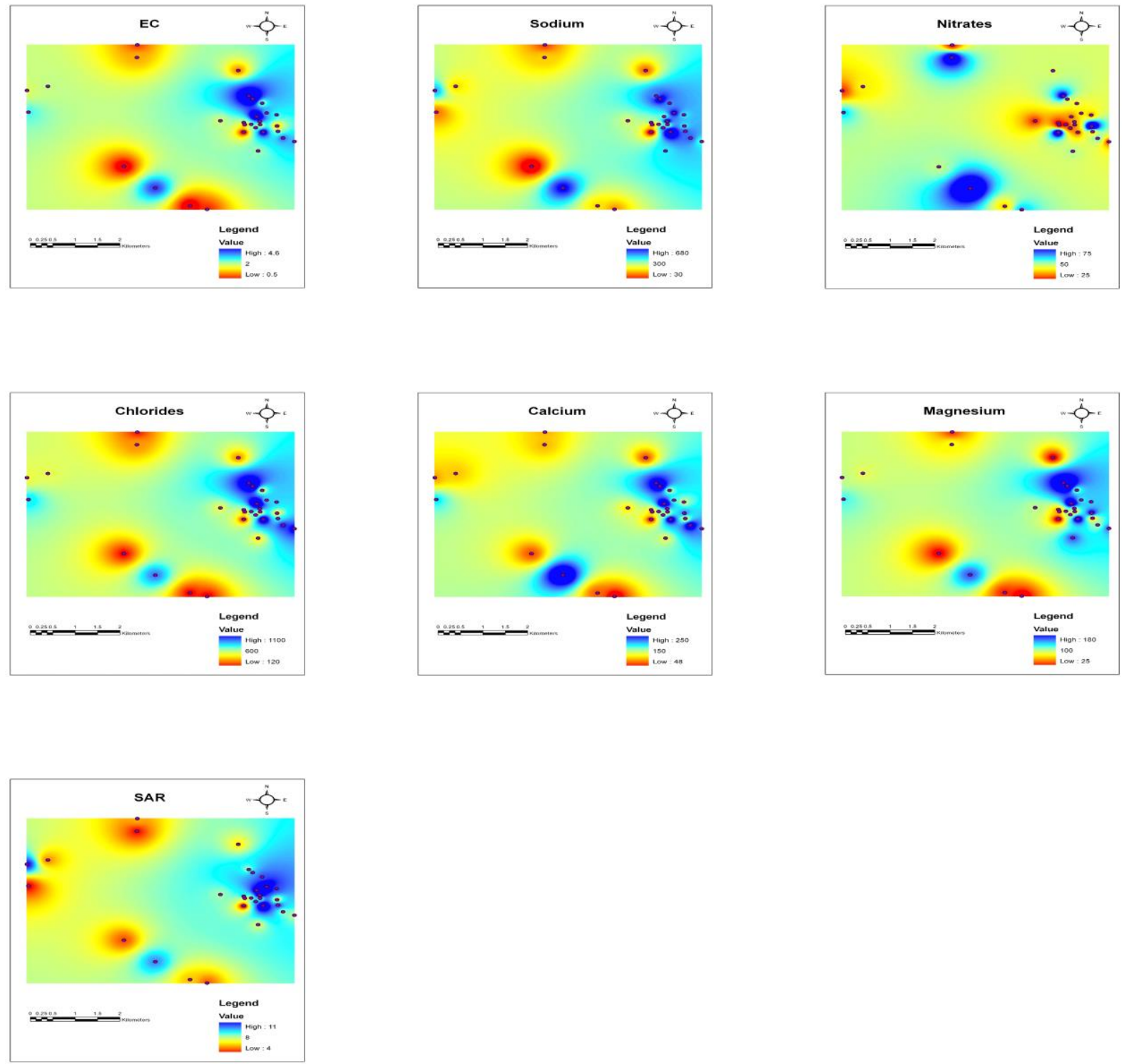

Figure 3. Spatial distribution of important groundwater quality parameters

The two tailed bivariate Spearman calculation is done for winter season, shown in Table 4. Table 4 shows the general statistic measures of all the parameters such as range, minimum, maximum, mean, standard error, standard deviation, variance of the study area etc. $\mathrm{pH}$ shows significant correlation at 0.05 levels with bicarbonate, alkalinity, nitrate and the SAR values. EC and total alkalinity values show significant correlation with all the major cations and anions at 0.05 levels. It is obvious that the correlation is very significant at 0.01 levels for EC and TDS calculated and the ratio is 0.932 . Total hardness show significant correlation with all major cations and anions except potassium and nitrates. COD correlates negatively with DO. Calcium, magnesium and sodium correlate well among them and also with the TDS, hardness, alkalinity, all the major cations and anions except potassium and nitrate. Chlorides correlate well with the TDS calculated and the continuous increase in chloride concentration shows that there is a possible contamination from leachates. Similarly, SAR actual and SAR adjusted also show significant correlation at 0.01 levels and the ratio is 0.994 . Also, both SAR values show that the correlation with sodium is 
significant at 0.01 levels and the ratio is 0.91 and 0.918 since the SAR values is directly proportional to sodium. Both the SAR values and TDS calculated show significant correlation with bicarbonate at 0.01 levels and the ratio are $0.561,0.591$ and 0.694 . The correlation between SAR values and TDS calculated show significant correlation at 0.01 levels and the ratio are 0.548 and 0.585 . The SAR values and TDS calculated show significant correlation with total alkalinity at 0.01 levels and the ratio are 0.559. 0.594 and 0.641 . TDS value shows significant correlation with calcium, magnesium and sodium at 0.01 levels and the ratio is $0.936,0.885$ and 0.815 . Sodium shows significant correlation with chloride and bicarbonate at 0.01 levels, and the ratio is 0.681 and 0.640

\subsection{Spatial distribution of groundwater quality}

Spatial distribution was drawn for average groundwater quality of all the seasons which is shown in Fig. 3. The direction specified throughout this paper has been referenced with respect to the location of municipal waste disposal and dump site. The spatial distribution is drawn for important ground water quality parameters such as EC, sodium, nitrates, calcium, magnesium, chloride and SAR. The groundwater quality is badly affected at two places in the study area. One of the affected area has been located in the region of movement of leachate of solid waste, i.e., on the northeastern side. The other area is spread throughout the study area, but the southwestern side is the most affected where larger area of agriculture is being practiced. The leachate and groundwater movement starts towards eastern direction from solid waste dump yard and changes its direction to the southern side as shown by contours of Fig. 2. $\mathrm{pH}$ is slightly alkaline along the groundwater flow path of the disposal site. TDS or EC, total alkalinity, chloride, calcium and magnesium is high along the flow path of groundwater or leachate i.e., on the eastern side of the solid waste dump yard. The areas where agriculture is practiced are affected with $\mathrm{pH}$, calcium, sulphate and nitrate. The study area is practicing predominantly agriculture and the most affected area is on the southwestern side of the disposal area. The most affected area invariably by all the cations and anions is located in the northeastern side of the disposal site which is along the flow path of groundwater and leachate from solid waste dumping yard

\subsection{Classification and Grouping}

The classification and clustering are studied through dendrogram for both winter and summer seasons which are shown in Fig. 4 and Fig. 5 respectively. The dendrogram for winter season has three significant linkage groups and they are irrigation quality parameters linkage, conductivity parameters linkage and hardness parameters linkage. The other linkages are at a long cluster distance and are insignificant. The first linkage group has direct relation among them which are SAR actual, SAR adjusted and $\mathrm{NO}_{3}$. The second linkage group is EC and chlorides which indicates that the increase of chloride concentration contributes more to the EC. This linkage indicates that the leachates of solid waste infiltrate into the groundwater. The third linkage is total hardness and magnesium, which shows that the hardness increase is mainly due to the magnesium which is due to the dolomite weathering from mining and processing activities.

The dendrogram for the summer season is shown in Fig. 5. There was no linkage between chloride and sulfate, chloride and TDS, and widening of TDS and Total hardness. This indicates that the leachate infiltration phenomenon is either least or retarded during summer season.

\section{HIERARCHICAL CLUSTER ANALYSIS}

Dendrogram for Winter season using Arerage Linkage (Betw een Groups)

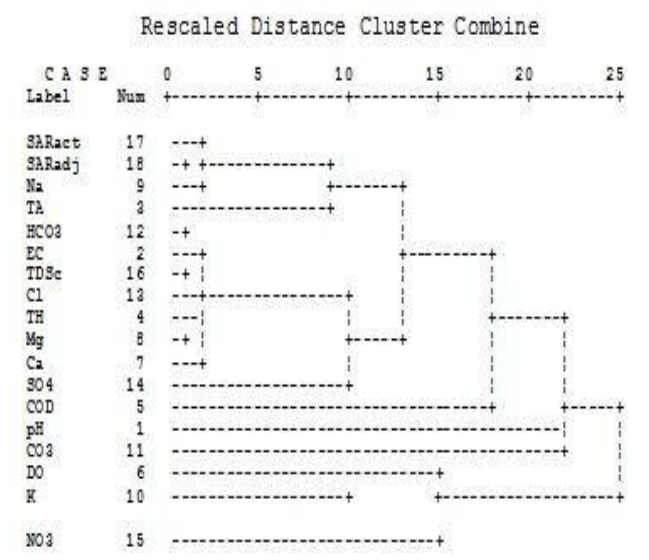

Figure4. Dendrogram for winter season

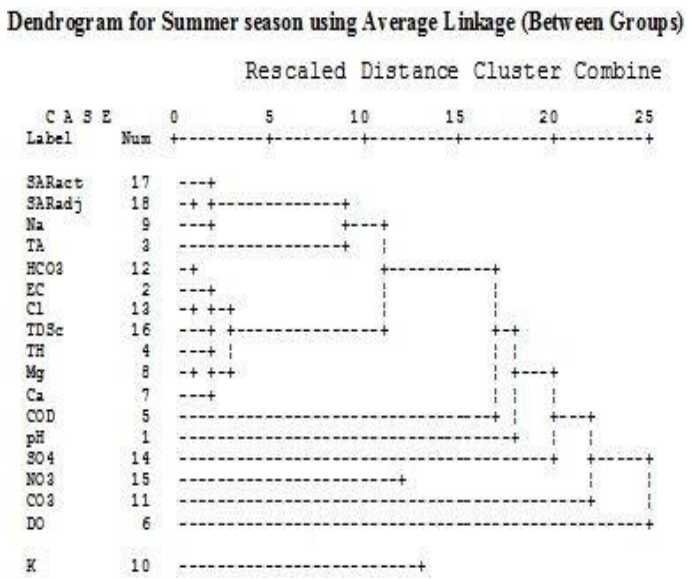

Figure 5. Dendrogram for Summer season

types of Gibbs plot have been drawn. The first type of the plot is drawn with TDS in $\mathrm{mg} \mathrm{l}^{-1}$ versus sum of $\mathrm{Na}, \mathrm{K}$ and $\mathrm{Ca}$ ratio in meq $\mathrm{I}^{-1}$ which is shown in Fig. 6 . The second type of Gibbs plot is drawn with TDS in $\mathrm{mg} \mathrm{l}^{-1}$ versus sum of $\mathrm{Cl} \&$ $\mathrm{HCO}_{3}$ ratio in meq $\mathrm{l}^{-1}$ which is shown in Fig. 7. Normally the
The geological phenomenon of the soil is generally inferred with the Gibbs plot. Gibbs plot has been drawn to find out the interaction of the soil with water or groundwater. Two 
interaction that shall be inferred from this type of plot is classified as dilution, evaporation, precipitation, and weathering phenomenon. The first type of Gibbs plot drawn for the samples shows that all the sampling points lie in the region of evaporation and dilution, and more precisely it is dominated by evaporation for both winter

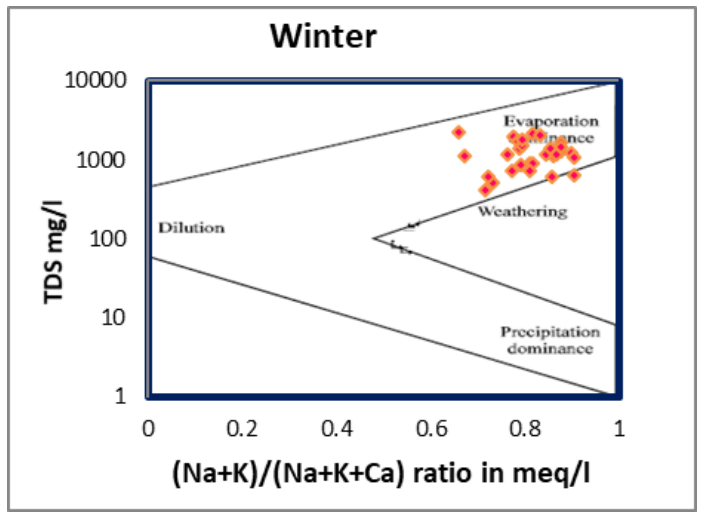

and summer seasons. The second type of Gibbs plot shows that the region is dominated by both the dilution and evaporation phenomenon. The dilution effect is more predominant during the winter season, as can be seen from the diagram.

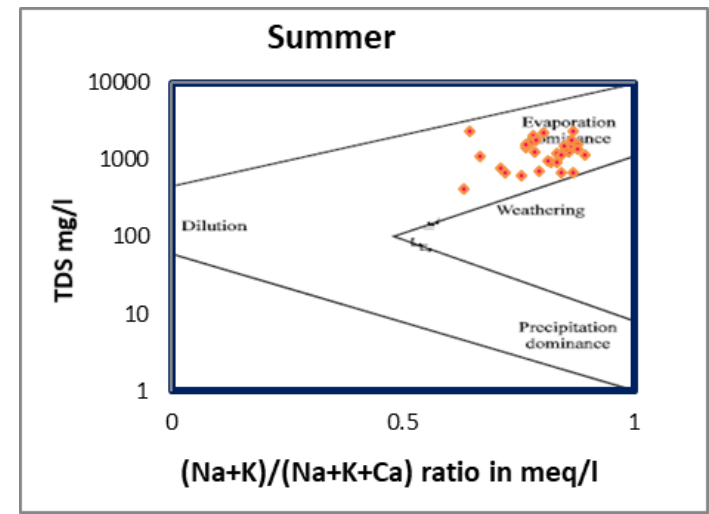

Figure 6. Gibb's plot I diagram
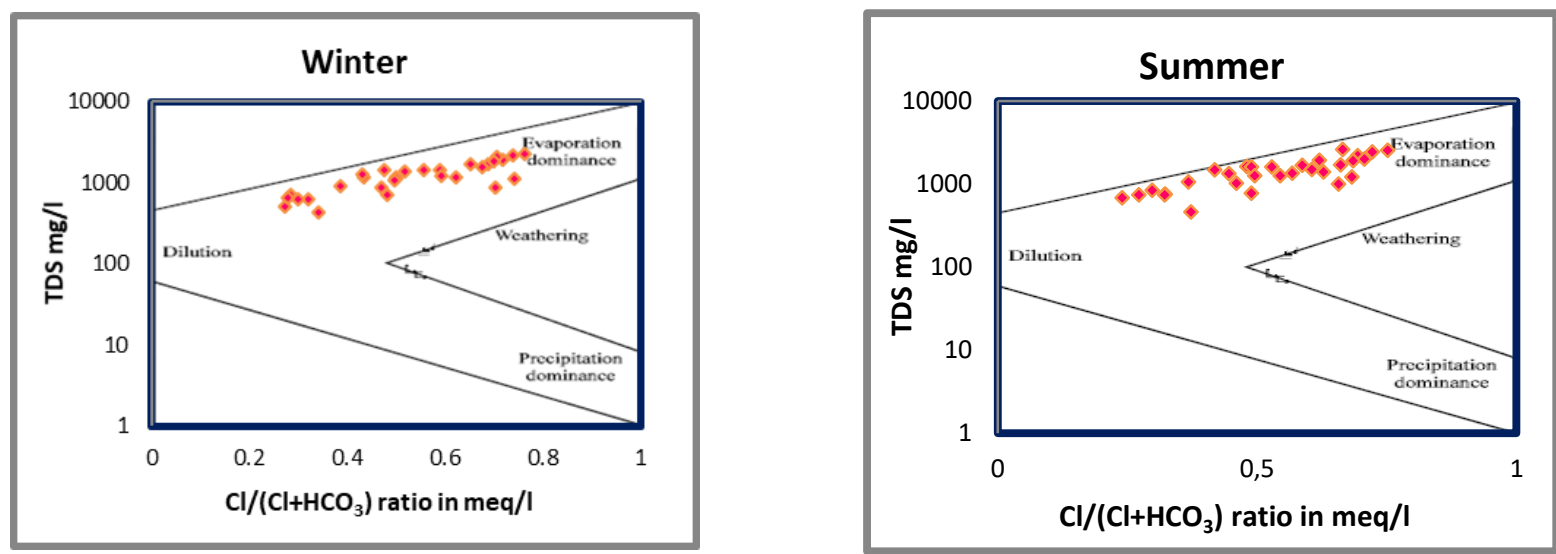

Figure 7. Gibb's plot II diagram

\subsection{Irrigation quality analysis of groundwater}

The hydro geochemical characteristics of groundwater are analyzed from piper diagram (Piper, 1944) which is shown in Fig 8 . It is seen from the quaternary diagram that the distribution of water types is two in both summer and winter season. The quartenary diagram shows that the groundwater is $\mathrm{NaCl}$ type and bicarbonates of $\mathrm{Ca}$ and $\mathrm{Mg}$ for both the seasons. The $\mathrm{NaCl}$ type shows the possible contamination of groundwater from leachates. As can be seen from the tri linear plots of both the cation and anion, the species that are dominant in groundwater samples are in the order of $\mathrm{Na}+\mathrm{K}, \mathrm{Ca}+\mathrm{Mg}, \mathrm{Cl}$ and $\mathrm{HCO}_{3}$ for both the winter and summer seasons. The cation tri linear plots are in line with $\mathrm{Na}+\mathrm{K}$, but anion samples are lumped towards carbonate and chloride. So, the dominant species of cations and anions in groundwater around the study area is $\mathrm{Na}^{+}$ions and $\mathrm{Cl}^{-}, \mathrm{HCO}_{3}$, ions for both the seasons. The cations align with $\mathrm{Na}+\mathrm{K}$ apex and anions align with carbonate and chloride apex. This tri linear piper diagram also suggests groundwater contamination by the leachates of solid waste and due to carbonate weathering by processing industries.

The Wilcox diagram has been used to assess the sodium and EC hazard qualitatively for groundwater used in irrigation (Wilcox, 1948). The Wilcox diagram is plotted using \%sodium versus EC in $\mu \mathrm{S} / \mathrm{cm}$. The percentage sodium ratio is calculated as follows:

$$
\mathrm{Na} \%=\frac{(\mathrm{Na}+\mathrm{K}) * 100}{(\mathrm{Na}+\mathrm{K}+\mathrm{Ca}+\mathrm{Mg})}
$$

Fig. 9 shows the sodium and EC hazard of groundwater samples. The Wilcox diagram qualitatively depicts the groundwater as excellent to good, good to permissible, permissible to doubtful and doubtful to unsuitable of groundwater in irrigation. The groundwater quality is relatively better during the winter season than the summer season. It is obvious that the winter provides recharge, and thereby dilution occurs. During winter, out of 30 samples, five samples fall in the region of excellent to good, seven samples in good to permissible, 12 samples in permissible to doubtful and six samples fall in doubtful to unsuitable 
regions. While during Summer season 5 samples fall in the region of excellent to good, 9 samples fall in the region of Good to permissible, eight samples fall in the region of

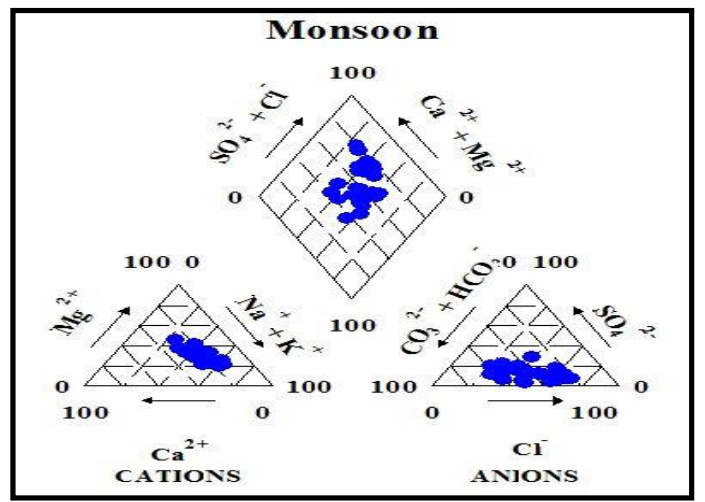

permissible to doubtful, and eight samples fall in doubtful to unsuitable quality for irrigation purposes.

Figure 8. Piper diagram
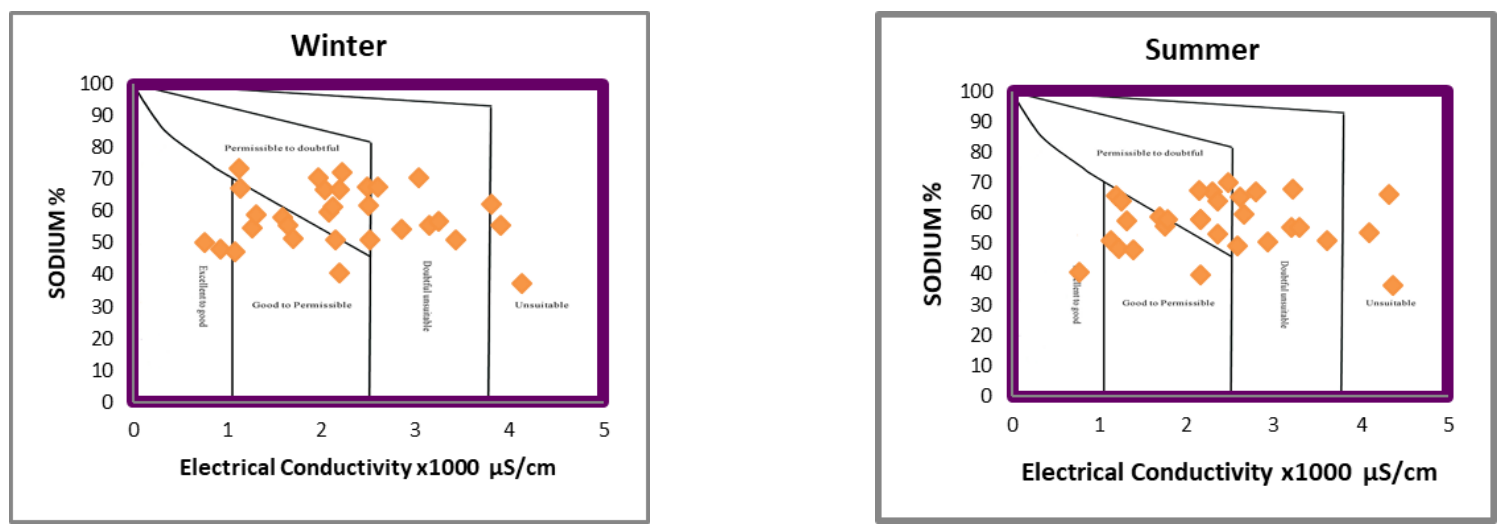

Figure 9a. Wilcox diagram for classification of irrigation waters

The USSL plot is similar to Wilcox but it shows the intensity of sodium \& conductivity hazard represented from 1 to 4 scale with prefix of $\mathrm{S}$ for sodium \& $\mathrm{C}$ for conductivity (Wilcox 1955). The sodium hazard is represented as S1, S2, S3, S4 and conductivity hazard as C1, C2, C3, C4. The classification from 1 to 4 depicts hazard for irrigation quality of water as Low, Medium, High and Very high. The quality of groundwater samples is better during winter than summer seasons. During winter season 11 samples fall in C3-S1 region and seven samples fall in C3-S2, 10samples in C4-S2 and two samples C4-S3 region. During the summer season 11 samples lie in the region of C3-S1, 14 samples lie in C4-S2, and four samples lie in C4-S3 region. The groundwater conductivity hazard varies from high to very high i.e., all the samples lie in C3 or C4. Similarly, sodium hazard varies from low to high i.e., S1 to S4. A majority of the groundwater samples show very high EC hazard and medium Sodium hazard.

The relative rate of infiltration is used to infer the groundwater penetration capacity of the soil (Rhoades 1968). This is studied with Rhoade's plot which describes the changes in penetration capacity of the soil with the quality of the applied groundwater. This Rhoade's plot is shown in Fig. 10. Out of 30 samples, twenty-eight samples plotted in the region of "no reduction" in the relative rate of infiltration. Only two samples lie in the region of a "slight reduction" in the relative rate of infiltration. Five samples lie at the boundary of "no reduction and slight reduction" zone. The above plot shows that if SAR increases with increase in EC, it shall always lie in the zone of "no reduction" in relative rate of infiltration. Conversely if SAR alone abnormally increases, then the groundwater quality enters into the zone of "slight reduction" and then to "severe reduction" in relative rate of infiltration. Similarly, if EC alone increases, then all the points will lie in the "no reduction" zone. This diagram as adapted from Rhoades 1977; and Oster and Schroer 1979, shows that when the EC alone comparatively increases then the points move towards no reduction zone. It shows that, if $\mathrm{Na}$ does not contribute to the increase in TDS but other parameters such as hardness parameters $\mathrm{Ca}, \mathrm{Mg}$ do contribute, then there shall be a decrease in the relative reduction rate of infiltration i.e. the groundwater quality becomes better, when applied onto the field. The above conditions indicate that the salinity must be compensated with hardness so as to make the ground water amenable for irrigation. So, in general, gypsum is added to the field as a soil conditioner to make it amenable for irrigation. The groundwater is suitable for irrigation except at five sampling points which lie on the border of no reduction to slight reduction. 

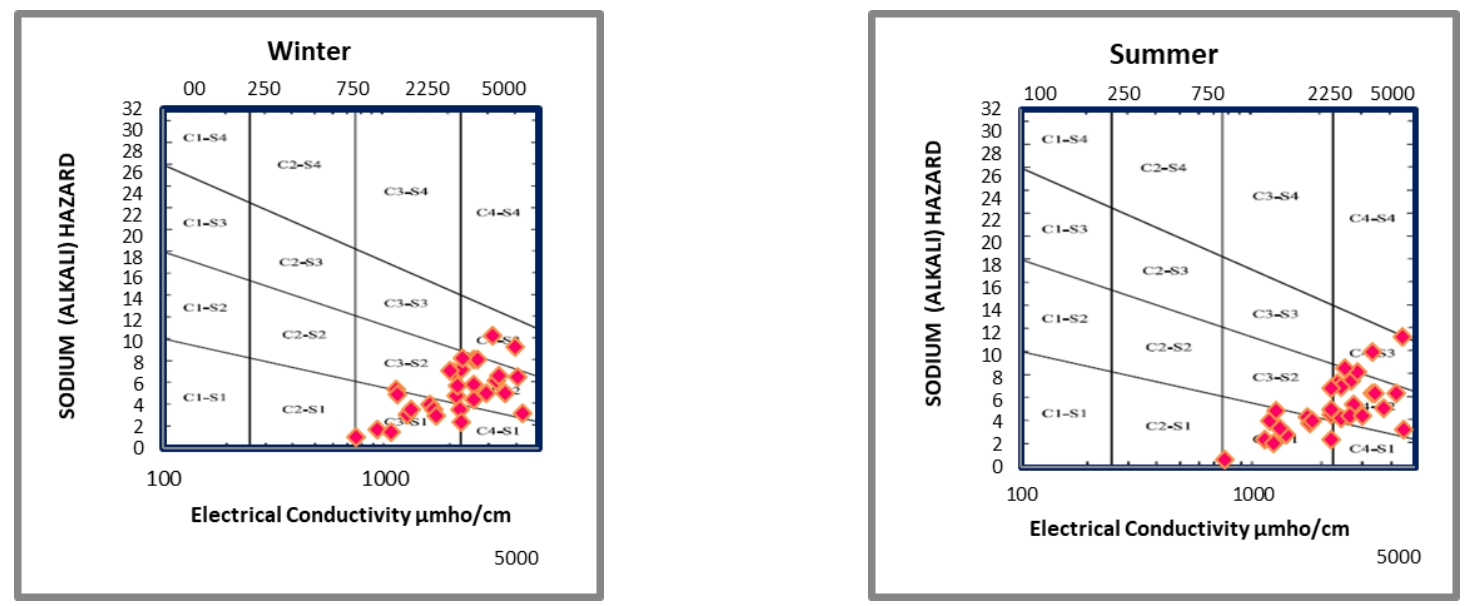

Figure 9b. USSL DIAGRAMS for classification of Irrigation waters
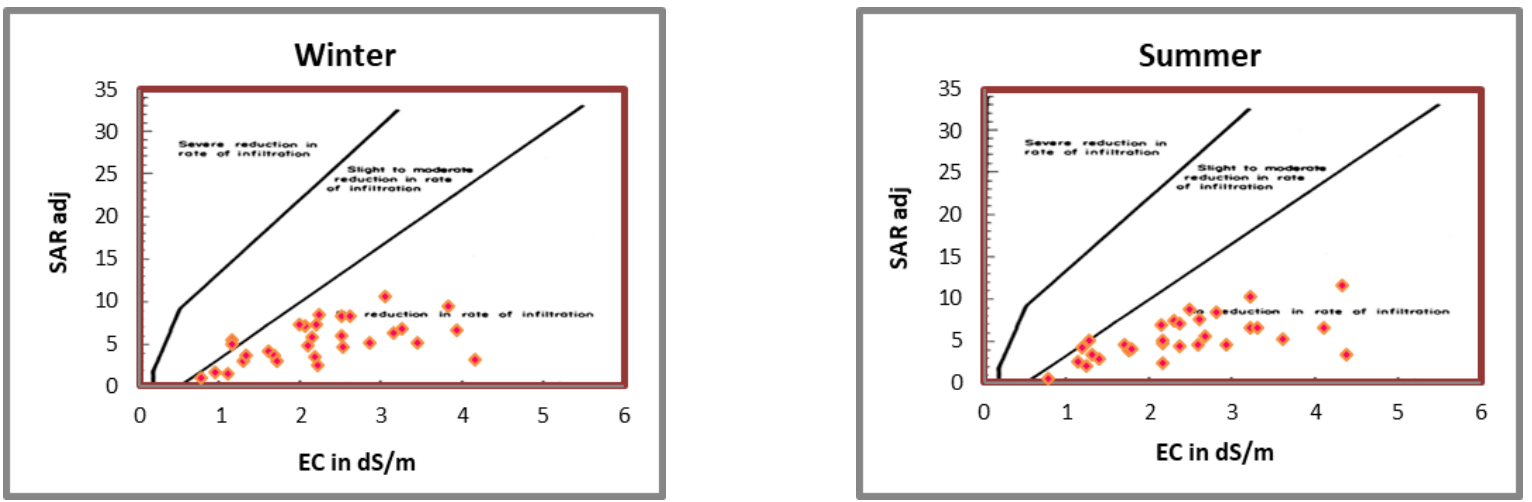

Figure 10. Rhoade's diagram for analysis of soil infiltration capacity

\section{Conclusion}

The dominant chemical cation species in the majority of the groundwater samples are in the order of $\mathrm{Na}>\mathrm{Ca}>\mathrm{Mg}>\mathrm{K}$ and anion species are in the order of $\mathrm{HCO} 3>\mathrm{Cl}>\mathrm{SO} 4>\mathrm{NO} 3$. Gibbs plot shows the geological phenomenon is dominated by evaporation and dilution. Rhoades plot shows there is no appreciable reduction in the rate of infiltration of the soil by the application of these groundwater samples except at two locations where it gets slightly affected. USSL diagram shows that the majority of the groundwater samples are affected by high TDS or conductivity hazard, and medium sodium hazard. Piper plot shows that two types of groundwater occur in both the seasons and the ground water is dominated by sodium, calcium, magnesium, chloride, and bicarbonates. Wilcox plot shows that the majority of the groundwater samples are in the range of "permissible" to "doubtful to unsuitable" for use in irrigation. SARadj values show that the quality of groundwater is suitable for irrigation at all locations except at two points which are located nearby municipal waste disposal sites. Statistical analysis, such as dendrogram study shows that the leachate infiltration is predominant during the winter season than summer season. Spatial distribution study and contour of the study area show that the flow path of the groundwater is towards the southeastern direction. The high concentration of TDS and chloride in groundwater in the southeastern region of disposal sites show contamination by solid waste leachates. The nitrate concentration is generally spread in all the areas and exceeds the limit in the wells surrounded by agriculture practiced areas. The highest concentration of calcium and magnesium occur in the groundwater in the northeastern region of municipal solid waste disposal and is due to processing of dolomites by several small-scale industries. This study shows that the leachate from open dump yard of municipal solid waste contaminates the groundwater along its flow path located in the southeastern region from the point of the municipal disposal site. The eastern region of the study area from municipal solid waste disposal site is the most affected and the groundwater quality needs to be assessed before irrigation.

\section{Acknowledgement}

We thank Thiagarajar College of Engineering, Madurai, our institution for providing us the laboratory facilities to test, characterize and analyze groundwater samples, resource facilities for deepening our knowledge through library, e-resources, journals, software and internet required for conducting this research study successfully. We thank the Department of United States Geological Survey for distributing the DEM images, free software as well as several Excel files in their websites to plot various irrigation quality diagrams, which are very useful for this 
study. We thank all the people for their valuable suggestion and comments during the writing of this paper. We also thank all the authors referred herein and to the authors contributing similar nature of the work to the world for better and better understanding of the complex soil and groundwater pollution. Finally, we thank all the peer reviewers for their fruitful comments to enhance the quality of this paper.

\section{References}

APHA-AWWA-WPCF, Standard Methods for the Examination of Water and Wastewater, 20thEds American Public Health Association, Washington, DC, USA (1999).

Bower C.A., Ogata G. and Tucker J.M. (1968), Sodium hazard of irrigation waters as influenced by leaching fraction and by precipitation or solution of calcium carbonate, Soil Sci., 106(1), 29-34.

Bower C.A., Wilcox L.V., Akin G.W. and Keyes M.G. (1965), An index of the tendency of $\mathrm{CaCO}_{3}$ to precipitate from irrigation waters, SSSA Proc., 29(1), 91-92.

De S., Maiti S.K., Hazra T., Debsarkar A. and Dutta A. (2016), Leachate characterization and identification of dominant pollutants using leachate pollution index for an uncontrolled landfill site, Global Journal of Environmental Science and Management, 2(2), 177-186.

De S., Maiti S.K., Hazra T., Debsarkar A. and Dutta A. (2017), Appraisal of seasonal variation of groundwater quality near an uncontrolled municipal solid waste landfill in Kolkata, India, Global NEST Journal, 19(3), 367-376.

Demirbilek D., Onal A.O., Demir V., Uslu G. and Arslanoglu-Isik H. (2013), Characterization and pollution potential assessment of Tunceli, Turkey municipal solid waste open dumping site leachates, Environmental Monitoring and Assessment, 185, 9435-9449.

FAO Irrigation and Drainage Paper 29, Rev. 1. Rome, Italy: Food and Agricultural Organization of the United Nations.

Herman Bouwer (1978), Groundwater Hydrology, Edition 2014, TATA McGraw Hill, New Delhi.

Kalavrouziotis I.K. (20015), The reuse of municipal Wastewater In soils, Global NEST Journal, 17(3), 474-486.

Kale S.S., Kadam A.K. and Kumar S. (2010), Evaluating pollution potential of leachate from landfill site, from the Pune metropolitan city and its impact on shallow basaltic aquifers, Environmental Monitoring and Assessment, 162, 327-346.

Karanth K.R. (1987) Ground Water Assessment, Development and Management, twelfth reprint 2008, TATA McGraw Hill, New Delhi.

Lo I.M.C. (1996), Characteristics and treatment of leachates from domestic landfills, Environment International, 22, 4, 433-442.

Maiti S. K., De S., Hazra T., Debsarkar A. and Dutta A. (2016), Characterization of Leachate and Its Impact on Surface and Groundwater Quality of a Closed Dumpsite-A Case Study at Dhapa, Kolkata, India, Procedia Environmental Sciences, 35, 391-399.

Mohsen Jalali (2011), Hydrogeochemistry of Groundwater and its suitability for Drinking and Agricultural use in Nahavand, Natural Resources Research, 20(1), 65-73.

Mor S., Ravindra K., Dahiya R. and Chandra A. (2006), Leachate characterization and assessment of groundwater pollution near municipal solid waste landfill site, Environmental Monitoring and Assessment, 118, 435-456.
Nagarajan R., Thirumalaisamy S. and Lakshumanan E. (2012), Impact of leachate on groundwater pollution due to nonengineered municipal solid waste landfill sites of erode city, Tamil Nadu, India, Iranian Journal of Environmental Health Science and Engineering, 9, 35.

Nash H. and McCall J.G.H. 1994 Groundwater Quality. Chapman \& Hall, London.

NECD. 2005. Salinity management for soil and water: Student guide. Fort Worth, Tex.: USDA-NRCS National Employee Development Center.

Nguyen T.T., Akira K.A., Tong T.N., Nakagawa N., Amaguchi H. and Gilbuena JrR. (2014), Hydrogeochemical characteristics of groundwater from the two main aquifers in the Red River Delta, Vietnam, Journal of Asian Earth Sciences, 93, 180-192.

Pande G., Sinha A. and Agrawal S. (2015), Impacts of Leachate percolation on ground water quality: A case study of Dhanbad city, Global NEST Journal, 17(1), 162-174.

Parameswari K., Mudgal B.V. and Nelliyat P. (2012), Evaluation of groundwater contamination and its impact: an interdisciplinary approach, Environment Development and Sustainability, 14, 725-744.

Pechlivanidis I.G., Olsson J, Sharma D., Bosshard T. and Sharma K.C. (2015), Assessment of the Climate Change impacts on the Water Resources Of The Luni Region, India, Global NEST Journal, 17(1), 29-40.

Piper A.M. (1944), A graphical procedure in the geochemical interpretation of water analysis, Transactions-American Geophyscal Union, 25, 914-928.

Ramesh K. and Elango L. (2012), Groundwater quality and its suitability for domestic and agricultural use in Tondiar river basin, Tamil Nadu, India, Environmental Monitoring and Assessment, 184, 3887-3899.

Rhoades J.D. (1968), Mineral-weathering correction for estimating the sodium hazard of irrigation waters, SSSA Proc., 32(5), 648-651.

Suarez D.L. (1981), The relation between phase and sodium adsorption ratio (SAR) and an alternative method of estimating SAR of soil and drainage waters, SSSA J., 45(3), 469-475.

Wilcox L.V. (1948) The quality of water for irrigation use, U.S. Department of Agriculture, Technical Bulletin 962 (40), Washington, DC: U.S. Department of Agriculture.

Wilcox L.V. (1955) Classification and use of Irrigation waters, United States Salinity Laboratory, U.S. Department of Agriculture, Technical Bulletin 969 (192), Washington, DC: U.S. Department of Agriculture

Yidana S.M., Banoeng-Yakubo B. and Akabzaa T.M. (2010), Analysis of groundwater quality using multivariate and spatial analyses in the Keta basin, Ghana, Journal of African Earth Sciences, 58, 220-234. 